\title{
Palynological evolutionary trends within the tribe Mentheae with special emphasis on subtribe Menthinae (Nepetoideae: Lamiaceae)
}

\author{
Hye-Kyoung Moon $\cdot$ Stefan Vinckier $\cdot$ \\ Erik Smets · Suzy Huysmans
}

Received: 13 December 2007/ Accepted: 28 March 2008/Published online: 10 September 2008

(c) Springer-Verlag 2008

\begin{abstract}
The pollen morphology of subtribe Menthinae sensu Harley et al. [In: The families and genera of vascular plants VII. Flowering plants-dicotyledons: Lamiales (except Acanthaceae including Avicenniaceae). Springer, Berlin, pp 167-275, 2004] and two genera of uncertain subtribal affinities (Heterolamium and Melissa) are documented in order to complete our palynological overview of the tribe Mentheae. Menthinae pollen is small to medium in size (13-43 $\mu \mathrm{m})$, oblate to prolate in shape and mostly hexacolpate (sometimes pentacolpate). Perforate, microreticulate or bireticulate exine ornamentation types were observed. The exine ornamentation of Menthinae is systematically highly informative particularly at generic level. The exine stratification in all taxa studied is characterized by unbranched columellae. Orbicules are consistently absent in Menthinae. Our palynological data are interpreted in a phylogenetic context at tribal level in order to assess the systematic value of pollen characters and to evaluate the existing molecular phylogenies for this group. Pollen morphology suggests Heterolamium as a close relative of subtribe Nepetinae and supports the molecular affinity of Melissa to subtribe Salviinae.
\end{abstract}

H.-K. Moon $(\bowtie) \cdot$ S. Vinckier · E. Smets · S. Huysmans Laboratory of Plant Systematics, Institute of Botany and Microbiology, K.U.Leuven, Kasteelpark Arenberg 31, P.O.Box 2437, 3001 Louvain, Belgium

e-mail: hyekyoung.moon@bio.kuleuven.be

S. Vinckier

Center for Transgene Technology and Gene Therapy, Flanders Institute for Biotechnology (VIB-3), K.U.Leuven,

Campus Gasthuisberg, Herestraat 49, 3000 Louvain, Belgium

E. Smets

National Herbarium of the Netherlands, Leiden University Branch, P.O.Box 9514, 2300 RA Leiden, The Netherlands
Keywords Bireticulum $\cdot$ Mentheae $\cdot$ Menthinae . Nepetoideae · Palynology · Phylogeny ·

Exine ornamentation

\section{Introduction}

The pollen morphology of Lamiaceae has proven to be systematically valuable since Erdtman (1945) used the number of nuclei and the aperture number to divide the family into two subfamilies (i.e. Lamioideae: bi-nucleate and tricolpate pollen, Nepetoideae: tri-nucleate and hexacolpate pollen). While the circumscription of subfamily Lamioideae has been dramatically changed after Erdtman's treatment due to progress in molecular systematics, including for instance many genera previously placed in Verbenaceae, the subfamily Nepetoideae is a consistently supported monophyletic group based on both molecular and morphological evidence (Cantino 1992; Harley et al. 2004; Wagstaff et al. 1995). Examples of morphological synapomorphies for the latter subfamily are the presence of six colpi, although some variation in aperture number occurs sporadically, exalbuminous seeds and an investing embryo type (Cantino 1992). According to the most recent classification (Harley et al. 2004), Nepetoideae comprise three tribes: Elsholtzeae, Mentheae and Ocimeae.

Palynological studies in Nepetoideae have been restricted geographically or have been based on a limited number of taxa using mainly light microscopic observations (Afzal-Rafii 1983; Henderson et al. 1968; Varghese and Verma 1968; Vij and Kashyap 1975; Waterman 1960). In contrast to the subfamily Lamioideae in which many palynological data are published (Abu-Asab and Cantino 1992, 1993, 1994), only few genera of Nepetoideae are described using detailed scanning and transmission electron 
microscopic observations (Harley 1992; Harley et al. 1992; Rudall 1980; Wagstaff 1992).

Tribe Mentheae includes about 65 genera and 2,000 species, and represents almost one fourth of the currently recognized genera in Lamiaceae. Mentheae is the largest and economically most important tribe including many culinary herbs such as mint (Mentha), oregano (Origanum), savory (Satureja), sage (Salvia) and thyme (Thymus). Mentheae, which was paraphyletic or polyphyletic as circumscribed by Briquet (1897) and Wunderlich (1967), was greatly expanded by Cantino et al. (1992) to include Glechoneae, Hormineae, Lepechinieae, Meriandreae, Monardeae, Nepeteae, Prunelleae, Rosmarineae and Salvieae and is strongly supported as a monophyletic group by molecular data (Wagstaff et al. 1995, Table 1). More recently, traditionally segregated tribes were recognized at subtribal level by Harley et al. (2004), i.e., Salviinae, Menthinae and Nepetinae. Although tribe Mentheae is a monophyletic group, the monophyly of its subtribes is still questionable based on the existing molecular phylogenies (Trusty et al. 2004; Walker and Sytsma 2007).

Since a thorough palynological study of the entire tribe Mentheae was lacking (Wagstaff 1992), we have presented a detailed pollen study of subtribe Salviinae and Nepetinae with a strong emphasis on the type genera Salvia and $\mathrm{Ne}$ peta (Moon et al. 2008a, b). In addition, we have assessed the possible occurrence of orbicules in Salviinae and Nepetinae. Orbicules are small sporopollenin particles that can be produced in species with a secretory tapetum (Huysmans et al. 1998, 2000). The presence or absence of orbicules and their morphology can provide additional palynological characters that might have a phylogenetic significance (e.g., Huysmans et al. 1998; Raj and El-Ghazaly 1987; Vinckier and Smets 2002). All taxa studied in Salviinae and Nepetinae have smooth tapetal membranes without any patterned sporopollenin deposition, meaning that orbicules were not observed in our two previous studies.

In order to present a detailed palynological overview of the entire tribe Mentheae sensu Harley et al. (2004), the present study focuses on the third subtribe Menthinae including two unplaced genera Heterolamium and Melissa. We, therefore, aim to document and illustrate the pollen morphology as well as the ultrastructure of the pollen wall, and we want to trace the possible occurrence of orbicules in subtribe Menthinae sensu Harley et al. (2004) using LM, SEM and TEM. These observations are discussed in the light of our previous pollen studies in the two other subtribes Salviinae and Nepetinae, with special emphasis on the systematic significance of pollen characters within the entire tribe Mentheae. Additionally, palynological data of two currently unplaced genera Heterolamium and Melissa are incorporated to comment on their enigmatic taxonomic position.

\section{Materials and Methods}

Material

The present study is based on herbarium material of 58 species (66 specimens) from 42 genera of the subtribe Menthinae, collected from the following herbaria: BR, GH, K, LV, MO and S (acronyms follow Holmgren et al. 1990; for a complete list of specimens, see Appendix) and also in part from plants recently collected by the first author. Two monotypic genera Eriothymus and Kurzamra could not be studied because of lack of material. Since the genus $\mathrm{Lyc}$ opus has already been studied by Moon and Hong (2003), it was also excluded from the present study.

\section{SEM observations}

Standard acetolysis (Erdtman 1960; Reitsma 1969) destroys the colpus membranes, which may influences the natural pollen shape and size (Demissew and Harley 1992; Moon et al. 2008a, b). The subtribes Salviinae and Nepetinae showed a striking size difference according to treatment: critical point dried pollen grains were always smaller than acetolysed pollen grains (Harley 1992; Lens et al. 2005; Moon et al. 2008a, b; Schols et al. 2004). Taking this in consideration, all samples were critical point dried in this study for optimally preserving their natural size and shape.

For pollen and orbicule observations, dried flowers or buds were rehydrated for $1-2 \mathrm{~h}$ in the wetting agent Agepon ${ }^{\circledR}$ (Agfa Gevaert, Leverkusen, Germany; Agepon wetting agent:distilled water $=1: 200$ ). Anthers were separated from the flowers and the tips were removed with a razor blade to facilitate rehydration. After dissection, the anthers remained for one more hour in the wetting agent. Following dehydration in a graded acetone series, the material was critical point dried (CPD 030, Balzers). The dried anthers were mounted on stubs with double-sided adhesive tape. The locules were opened and the pollen grains were carefully removed with a cactus needle. The removed pollen grains were collected on the same stub for observation. The stubs were coated with gold (SPI-MOD$\mathrm{ULE}^{\mathrm{TM}}$ Sputter Coater, SPI Supplies, West Chester, PA, USA) prior to observation with a JEOL JSM-6360 scanning electron microscope at $10-20 \mathrm{kV}$. The size measurements of 15-20 fully developed pollen grains on SEM images were made using Carnoy 2.0 (Schols et al. 2002).

\section{Ultrastructure}

For transmission electron microscopy (TEM), the anthers from living material were directly fixed in $2.5 \%$ glutaraldehyde while dried anthers were rehydrated in $0.05 \mathrm{M}$ 
Table 1 Genera of tribe Mentheae sensu Harley et al. (2004) and their previous taxonomic positions

\begin{tabular}{|c|c|c|c|}
\hline $\begin{array}{l}\text { Tribe Mentheae sensu Harley } \\
\text { et al. (2004) }\end{array}$ & Bentham (1876) & Briquet (1897) & Wunderlich (1967) \\
\hline \multicolumn{4}{|l|}{ Subtribe Menthinae } \\
\hline $\begin{array}{l}\text { Acanthomintha (A.Gray) } \\
\text { Benth. \& Hook. f. }\end{array}$ & $\begin{array}{l}\text { Tribe Satureineae, subtribe } \\
\text { Melisseae }\end{array}$ & Tribe Glechoneae & Tribe Glechoneae \\
\hline Blephilia Raf. & Tribe Monardeae & Tribe Monardeae & Tribe Monardeae \\
\hline Bystropogon L’Hér. & $\begin{array}{l}\text { Tribe Satureineae, subtribe } \\
\text { Menthoideae }\end{array}$ & $\begin{array}{l}\text { Tribe Satureieae, subtribe } \\
\text { Thyminae }\end{array}$ & $\begin{array}{l}\text { Tribe Saturejeae, subtribe } \\
\text { Thyminae }\end{array}$ \\
\hline Cleonia $\mathrm{L}$. & Tribe Stachydeae & $\begin{array}{l}\text { Tribe Stachydeae, subtribe } \\
\text { Brunellinae }\end{array}$ & $\begin{array}{l}\text { Tribe Stachydeae, subtribe } \\
\text { Prunellinae }\end{array}$ \\
\hline Clinopodium L. & $\begin{array}{l}\text { Tribe Satureineae, subtribe } \\
\text { Melisseae (as Calamintha) }\end{array}$ & Genus Satureia sect. Clinopodium & Genus Satureja \\
\hline Conradina A. Gray & $\begin{array}{l}\text { Tribe Satureineae, subtribe } \\
\text { Melisseae }\end{array}$ & $\begin{array}{l}\text { Tribe Satureieae, subtribe } \\
\text { Melissinae }\end{array}$ & $\begin{array}{l}\text { Tribe Saturejeae, subtribe } \\
\text { Melissinae }\end{array}$ \\
\hline Cuminia Colla & $\begin{array}{l}\text { Tribe Satureineae, subtribe } \\
\text { Menthoideae }\end{array}$ & $\begin{array}{l}\text { Tribe Satureieae, subtribe } \\
\text { Menthinae }\end{array}$ & $\begin{array}{l}\text { Tribe Saturejeae, subtribe } \\
\text { Menthinae }\end{array}$ \\
\hline Cunila D. Royen ex L. & $\begin{array}{l}\text { Tribe Satureineae, subtribe } \\
\text { Menthoideae }\end{array}$ & $\begin{array}{l}\text { Tribe Satureieae, subtribe } \\
\text { Thyminae }\end{array}$ & $\begin{array}{l}\text { Tribe Saturejeae, subtribe } \\
\text { Thyminae }\end{array}$ \\
\hline $\begin{array}{l}\text { Cyclotrichium (Boiss.) } \\
\text { Manden. \& Scheng. }\end{array}$ & $\begin{array}{l}\text { Genus Calamintha (see } \\
\text { Clinopodium) }\end{array}$ & Genus Satureja sect. Cyclotrichum & N.I. \\
\hline Dicerandra Benth. & $\begin{array}{l}\text { Tribe Satureineae, subtribe } \\
\text { Melisseae (as Ceranthera) }\end{array}$ & $\begin{array}{l}\text { Tribe Satureieae, subtribe } \\
\text { Melissinae (as Ceranthera) }\end{array}$ & $\begin{array}{l}\text { Tribe Saturejeae, subtribe } \\
\text { Melissinae (as Ceranthera) }\end{array}$ \\
\hline Eriothymus (Benty.) Schmidt & $\begin{array}{l}\text { Tribe Satureineae, subtribe } \\
\text { Melisseae (as Keithia) }\end{array}$ & Genus Hedeoma & N.I. \\
\hline Glechon Spreng. & $\begin{array}{l}\text { Tribe Satureineae, subtribe } \\
\text { Melisseae }\end{array}$ & Tribe Glechoneae & Tribe Glechoneae \\
\hline Gontscharovia Boriss. & N.I. & N.I. & N.I. \\
\hline Hedeoma Pers. & $\begin{array}{l}\text { Tribe Satureineae, subtribe } \\
\text { Melisseae }\end{array}$ & $\begin{array}{l}\text { Tribe Satureieae, subtribe } \\
\text { Melissinae }\end{array}$ & $\begin{array}{l}\text { Tribe Saturejeae, subtribe } \\
\text { Melissinae }\end{array}$ \\
\hline Hesperozygis Epling & N.I. & N.I. & N.I. \\
\hline Hoehnea Epling & N.I. & N.I. & N.I. \\
\hline Horminum L. & $\begin{array}{l}\text { Tribe Satureineae, subtribe } \\
\text { Lepechineae }\end{array}$ & Tribe Hormineae & Tribe Hormineae \\
\hline Hyssopus L. & $\begin{array}{l}\text { Tribe Satureineae, subtribe } \\
\text { Menthoideae }\end{array}$ & $\begin{array}{l}\text { Tribe Satureieae, subtribe } \\
\text { Hyssopinae }\end{array}$ & $\begin{array}{l}\text { Tribe Saturejeae, subtribe } \\
\text { Hyssopinae }\end{array}$ \\
\hline Kurzamra Kuntze & $\begin{array}{c}\text { Tribe Satureineae, subtribe } \\
\text { Melisseae (as Soliera) }\end{array}$ & $\begin{array}{l}\text { Tribe Satureieae, subtribe } \\
\text { Melissinae }\end{array}$ & N.I. \\
\hline Lycopus L. & $\begin{array}{l}\text { Tribe Satureineae, subtribe } \\
\text { Menthoideae }\end{array}$ & $\begin{array}{l}\text { Tribe Satureieae, subtribe } \\
\text { Menthinae }\end{array}$ & $\begin{array}{l}\text { Tribe Saturejeae, subtribe } \\
\text { Menthinae }\end{array}$ \\
\hline Mentha L. & $\begin{array}{l}\text { Tribe Satureineae, subtribe } \\
\text { Menthoideae }\end{array}$ & $\begin{array}{l}\text { Tribe Satureieae, subtribe } \\
\text { Menthinae }\end{array}$ & $\begin{array}{l}\text { Tribe Saturejeae, subtribe } \\
\text { Menthinae }\end{array}$ \\
\hline Micromeria Benth. & $\begin{array}{l}\text { Tribe Satureineae, subtribe } \\
\text { Melisseae }\end{array}$ & Genus Satureia & Genus Satureja \\
\hline Minthostachys (Benth.) Spach & Genus Bystropogon & Genus Bystropogon & N.I. \\
\hline Monarda $\mathrm{L}$. & Tribe Monardeae & Tribe Monardeae & Tribe Monardeae \\
\hline Monardella Benth. & $\begin{array}{l}\text { Tribe Satureineae, subtribe } \\
\text { Menthoideae }\end{array}$ & $\begin{array}{l}\text { Tribe Satureieae, subtribe } \\
\text { Thyminae }\end{array}$ & $\begin{array}{l}\text { Tribe Saturejeae, subtribe } \\
\text { Thyminae }\end{array}$ \\
\hline $\begin{array}{l}\text { Neoeplingia Ramamoorthy, } \\
\text { Hiriart \& Medrano }\end{array}$ & N.I. & N.I. & N.I. \\
\hline $\begin{array}{l}\text { Obtegomeria P.D. Cantino \& } \\
\text { Doroszenko }\end{array}$ & N.I. & N.I. & N.I. \\
\hline Origanum L. & $\begin{array}{l}\text { Tribe Satureineae, subtribe } \\
\text { Menthoideae }\end{array}$ & $\begin{array}{l}\text { Tribe Satureieae, subtribe } \\
\text { Thyminae }\end{array}$ & $\begin{array}{l}\text { Tribe Saturejeae, subtribe } \\
\text { Thyminae }\end{array}$ \\
\hline Pentapleura Hand.-Mazz. & N.I. & N.I. & N.I. \\
\hline
\end{tabular}


Table 1 continued

\begin{tabular}{|c|c|c|c|}
\hline $\begin{array}{l}\text { Tribe Mentheae sensu Harley } \\
\text { et al. (2004) }\end{array}$ & Bentham (1876) & Briquet (1897) & Wunderlich (1967) \\
\hline Piloblephis Raf. & Genus Satureja (sect. Pycnothymus) & $\begin{array}{l}\text { Genus Satureja (sect. } \\
\text { Pycnothymus) }\end{array}$ & N.I. \\
\hline Pogogyne Benth. & $\begin{array}{l}\text { Tribe Satureineae, subtribe } \\
\text { Melisseae }\end{array}$ & $\begin{array}{l}\text { Tribe Satureieae, subtribe } \\
\text { Melissinae }\end{array}$ & $\begin{array}{l}\text { Tribe Saturejeae, subtribe } \\
\text { Melissinae }\end{array}$ \\
\hline Poliomintha A. Gray & $\begin{array}{l}\text { Tribe Satureineae, subtribe } \\
\text { Melisseae }\end{array}$ & Genus Hedeoma & N.I. \\
\hline Prunella L. & Tribe Stachydeae (as Brunella) & $\begin{array}{l}\text { Tribe Stachydeae, subtribe } \\
\text { Brunellinae (as Brunella) }\end{array}$ & $\begin{array}{l}\text { Tribe Stachydeae, subtribe } \\
\text { Prunellinae }\end{array}$ \\
\hline Pycnanthemum Michx. & $\begin{array}{l}\text { Tribe Satureineae, subtribe } \\
\text { Menthoideae }\end{array}$ & $\begin{array}{l}\text { Tribe Satureieae, subtribe } \\
\text { Thyminae (as Koellia) }\end{array}$ & $\begin{array}{l}\text { Tribe Saturejeae, subtribe } \\
\text { Thyminae }\end{array}$ \\
\hline Rhabdocaulon (Benth.) Epling & $\begin{array}{l}\text { Tribe Satureineae, subtribe } \\
\text { Melisseae (as Keithia) }\end{array}$ & Genus Hedeoma & N.I. \\
\hline Rhododon Epling & N.I. & N.I. & N.I. \\
\hline Saccocalyx Coss. \& Durieu & Genus Satureja & $\begin{array}{l}\text { Tribe Satureieae, subtribe } \\
\text { Melissinae }\end{array}$ & $\begin{array}{l}\text { Tribe Saturejeae, subtribe } \\
\text { Melissinae }\end{array}$ \\
\hline Satureja L. & $\begin{array}{l}\text { Tribe Satureineae, subtribe } \\
\text { Menthoideae }\end{array}$ & $\begin{array}{l}\text { Tribe Satureieae, subtribe } \\
\text { Melissinae }\end{array}$ & $\begin{array}{l}\text { Tribe Saturejeae, subtribe } \\
\text { Melissinae }\end{array}$ \\
\hline Stachydeoma Small & Genus Hedeoma & Genus Hedeoma & N.I. \\
\hline Thymbra L. & $\begin{array}{l}\text { Tribe Satureineae, subtribe } \\
\text { Melisseae }\end{array}$ & $\begin{array}{l}\text { Tribe Satureieae, subtribe } \\
\text { Melissinae }\end{array}$ & $\begin{array}{l}\text { Tribe Saturejeae, subtribe } \\
\text { Melissinae }\end{array}$ \\
\hline Thymus L. & $\begin{array}{l}\text { Tribe Satureineae, subtribe } \\
\text { Menthoideae }\end{array}$ & $\begin{array}{l}\text { Tribe Satureieae, subtribe } \\
\text { Thyminae }\end{array}$ & $\begin{array}{l}\text { Tribe Saturejeae, subtribe } \\
\text { Thyminae }\end{array}$ \\
\hline Zataria Boiss. & $\begin{array}{l}\text { Tribe Satureineae, subtribe } \\
\text { Menthoideae }\end{array}$ & $\begin{array}{l}\text { Tribe Satureieae, subtribe } \\
\text { Thyminae }\end{array}$ & $\begin{array}{l}\text { Tribe Saturejeae, subtribe } \\
\text { Thyminae }\end{array}$ \\
\hline Ziziphora L. & Tribe Monardeae & $\begin{array}{l}\text { Tribe Satureieae, subtribe } \\
\text { Melissinae }\end{array}$ & $\begin{array}{l}\text { Tribe Saturejeae, subtribe } \\
\text { Melissinae }\end{array}$ \\
\hline \multicolumn{4}{|l|}{ Subtribe Salviinae } \\
\hline Chaunostoma Donn. Sm. & N.I. & Incertae Sedis & N.I. \\
\hline Dorystaechas Boiss. \& Heldr. & Tribe Monardeae & Tribe Meriandreae & Tribe Meriandreae \\
\hline Lepechinia Willd. & $\begin{array}{l}\text { Tribe Satureineae, subtribe } \\
\text { Lepechineae }\end{array}$ & Tribe Lepechinieae & Tribe Lepechinieae \\
\hline Meriandra Benth. & Tribe Monardeae & Tribe Meriandreae & Tribe Meriandreae \\
\hline Perovskia Kar. & Tribe Monardeae & Tribe Meriandreae & Tribe Meriandreae \\
\hline Rosmarinus L. & Tribe Monardeae & Tribe Rosmarineae & Tribe Rosmarineae \\
\hline Salvia L. & Tribe Monardeae & Tribe Salvieae & Tribe Salvieae \\
\hline Zhumeria Rech.f. \& Wendelbo & N.I. & N.I. & N.I. \\
\hline \multicolumn{4}{|c|}{ Subtribe Nepetinae } \\
\hline $\begin{array}{l}\text { Agastache J.Clayton ex } \\
\text { Gronov. }\end{array}$ & N.I. & Tribe Nepeteae & Tribe Nepeteae \\
\hline Cedronella Moench & Tribe Nepeteae & Tribe Nepeteae & Tribe Nepeteae \\
\hline Dracocephalum L. & Tribe Nepeteae & Tribe Nepeteae & Tribe Nepeteae \\
\hline Drepanocaryum Pojark. & N.I. & N.I. & N.I. \\
\hline Glechoma L. & Genus Nepeta & Tribe Nepeteae & Tribe Nepeteae \\
\hline $\begin{array}{l}\text { Hymenocrater Fisch. \& } \\
\text { C.A.Mey. }\end{array}$ & Tribe Nepeteae & Tribe Nepeteae & Tribe Nepeteae \\
\hline $\begin{array}{l}\text { Lallemantia Fisch. \& } \\
\text { C.A.Mey. }\end{array}$ & Tribe Nepeteae & Tribe Nepeteae & Tribe Nepeteae \\
\hline Lophanthus Adans. & Tribe Nepeteae & Tribe Nepeteae & Tribe Nepeteae \\
\hline Marmoritis Benth. & Genus Nepeta & N.I. & N.I. \\
\hline Meehania Britton & N.I. & Tribe Nepeteae & Tribe Nepeteae \\
\hline
\end{tabular}


Table 1 continued

\begin{tabular}{|c|c|c|c|}
\hline $\begin{array}{l}\text { Tribe Mentheae sensu Harley } \\
\text { et al. (2004) }\end{array}$ & Bentham (1876) & Briquet (1897) & Wunderlich (1967) \\
\hline Nepeta L. & Tribe Nepeteae & Tribe Nepeteae & Tribe Nepeteae \\
\hline $\begin{array}{l}\text { Schizonepeta (Benth.) Briq. } \\
\text { Incertae Sedis }\end{array}$ & Genus Nepeta & Tribe Nepeteae & Tribe Nepeteae \\
\hline Heterolamium C. Y. Wu & N.I. & N.I. & N.I. \\
\hline Melissa $\mathrm{L}$. & $\begin{array}{l}\text { Tribe Satureineae, subtribe } \\
\text { Melisseae }\end{array}$ & $\begin{array}{l}\text { Tribe Satureieae, subtribe } \\
\text { Melissinae }\end{array}$ & $\begin{array}{l}\text { Tribe Saturejeae, subtribe } \\
\text { Melissinae }\end{array}$ \\
\hline
\end{tabular}

N.I. not indicated

sodium cacodylate buffer ( $\mathrm{pH}$ 7.3) prior to fixation. Fixed anthers were rinsed with $0.05 \mathrm{M}$ sodium cacodylate buffer $\left(\mathrm{pH} 7.3\right.$ ), followed by post fixation in $2 \% \mathrm{OsO}_{4}$. Prior to embedding in LR-White Resin (Polysciences Inc., Warrington, PA, USA), the material was dehydrated in a graded ethanol series. Semi-thin sections $( \pm 1 \mu \mathrm{m})$ were cut with a microtome (Reichert Jung Ultracut E), stained with $0.1 \%$ thionin $-0.1 \%$ methylene blue, and observed with a Leitz Dialux 20 microscope. The ultra-thin sections $(70 \mathrm{~nm})$ on copper grids were stained with uranyl acetate and lead citrate in an ultrastainer (LKB 2168), and observed with a Zeiss EM 900 transmission electron microscope at $50 \mathrm{kV}$.

Pollen terminology follows the Glossary of Pollen and Spore Terminology (Punt et al. 2007; http://www.bio.uu.nl/ $\sim$ palaeo/glossary/glos-int.htm).

\section{Results}

The pollen morphology of subtribe Menthinae is highly uniform. Therefore, we prefer to give a general pollen description for the subtribe with references to particular species when necessary. The major pollen features of all taxa investigated are summarized in Table 2 . Representative pollen grains are illustrated in Figs. 1-4.

\section{Size and shape}

Pollen grains are shed as monads and their size varies from small to medium $(P=13.0-43.3 \mu \mathrm{m})$. Mentha pulegium possesses the smallest pollen grains while Cleonia lusitanica and Monarda punctata have the largest pollen grains (Table 2). At infrageneric level the taxa studied have a rather narrow size range (Table 2).

The shape of pollen grains in equatorial view ranges from oblate to prolate $(P / E=0.67-1.72$; Fig. 1a-f). Suboblate to prolate-spheroidal shapes are common even within the same taxa (Table 2). The outline in polar view is circular, sometimes mixed with elliptic grains because of width of the mesocolpium area (Fig. 1g-l).

\section{Apertures}

All taxa studied have hexacolpate pollen grains. Pollen aperture heteromorphism only occurs in Prunella vulgaris and Pycnanthemum incanum with a few pentacolpate pollen grains (Fig. 1j).

Simple colpi are distributed symmetrically. The range of colpi lengths is $10.6-37.1 \mu \mathrm{m}$. Colpus length is strongly correlated with length of polar axis. Colpi ends are acute (Fig. 1) and the apocolpium index (AI) varies between 0.10 and 0.29 (Table 2).

Exine ornamentation

Three distinct exine ornamentation types are observed in Menthinae: bireticulate, microreticulate or perforate (Fig. 2). Based on the detailed configuration of the exine ornamentation three subtypes can be defined for the bireticulate pattern, and two subtypes for the microreticulate pattern.

\section{Type I: bireticulate}

A bireticulum consists of a non-congruent, two-layered reticulum. The main reticulum is referred to as the primary reticulum and the substratum as the secondary reticulum. Three subtypes can be defined based on the number of secondary lumina in each primary lumen. Type I-1: The primary muri are more than twice as thick as the secondary muri. Primary lumina are continuous and irregular to rounded and slightly shallow. The secondary reticulum is microreticulate and the number of secondary lumina does not exceed ten in each primary lumen. Observed in: Gontscharovia, Horminum, Melissa, Monardella, Thymus, Ziziphora (Fig. 2a, b). Type I-2: The primary muri are thicker than the secondary muri. The shape of the primary lumina is rounded and continuous. The secondary lumina 


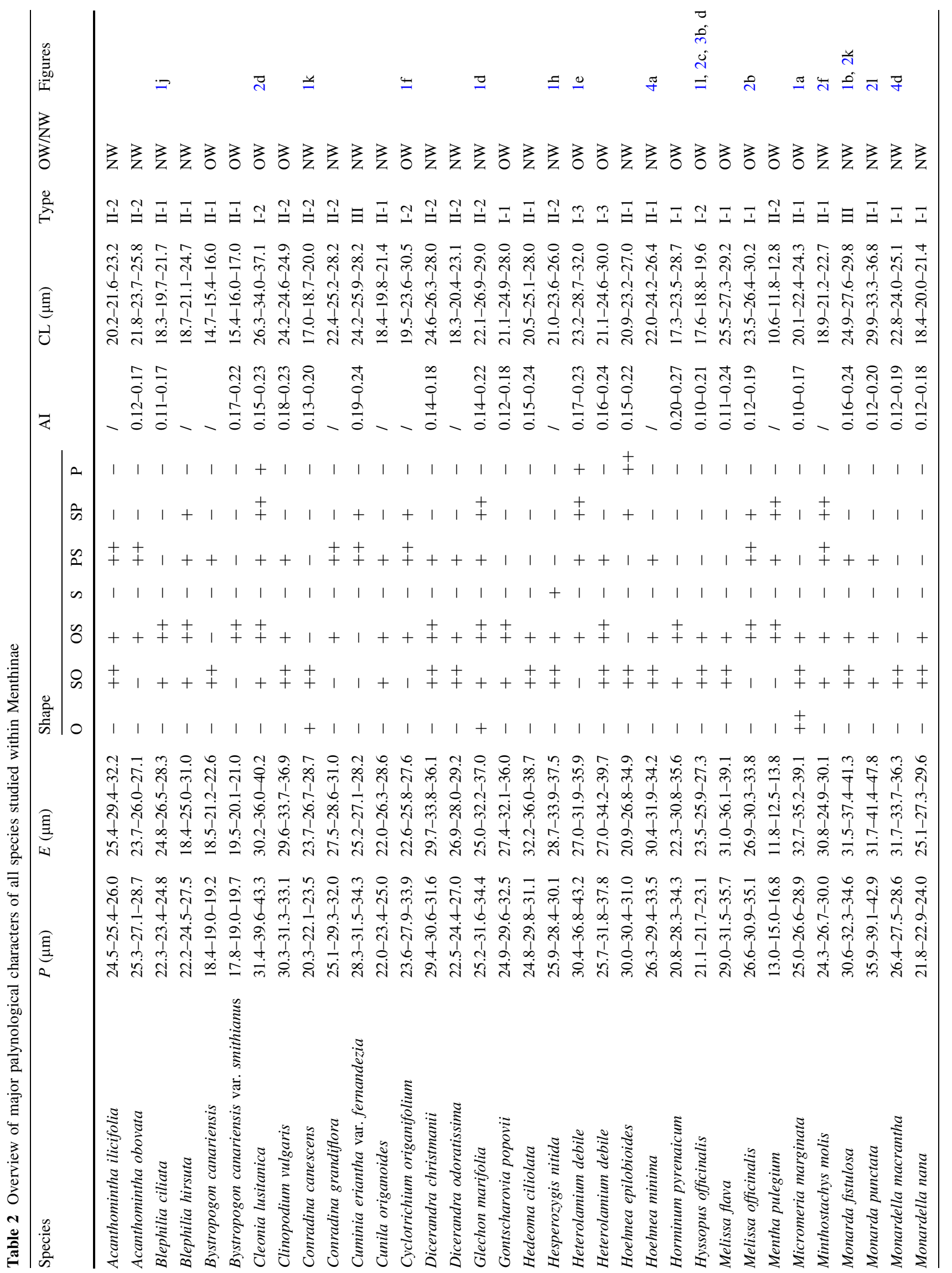




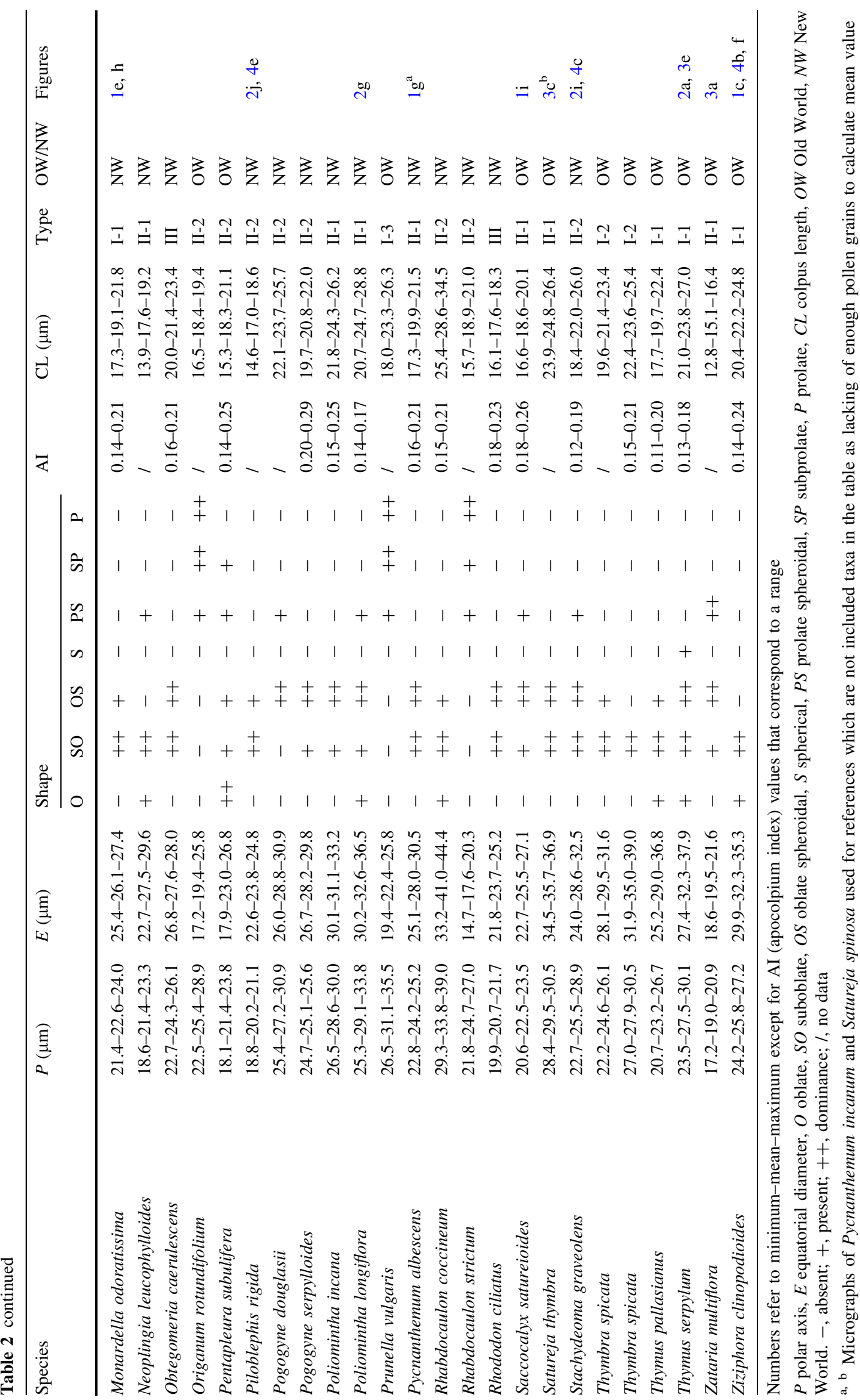


Fig. 1 SEM micrographs of pollen grains of Menthinae. a-f Variation of pollen shape in the equatorial view. g-l Polar view with variations of shape and aperture number. a Oblate pollen grain with elliptic outline of Micromeria marginata.

Suboblate pollen grain,

b Monarda fistulosa,

c Ziziphora clinopodioides.

d Oblatespheroidal pollen grain with circular outline, Glechon marifolia. Monardella odoratissima, e oblate spheroidal pollen, $\mathbf{h}$ circular outline. f Subprolate pollen grain of Cyclotrichium origanifolium. g Pentacolpate pollen grain of Pycnanthemum incanum. Hexacolpate pollen grain with circular shape, h Monardella odoratissima, i Saccocalyx satureioides,

j Blephilia ciliata. Hexacolpate pollen grain with elliptic shape, k Conradina canescens, 1 Hyssopus officinalis
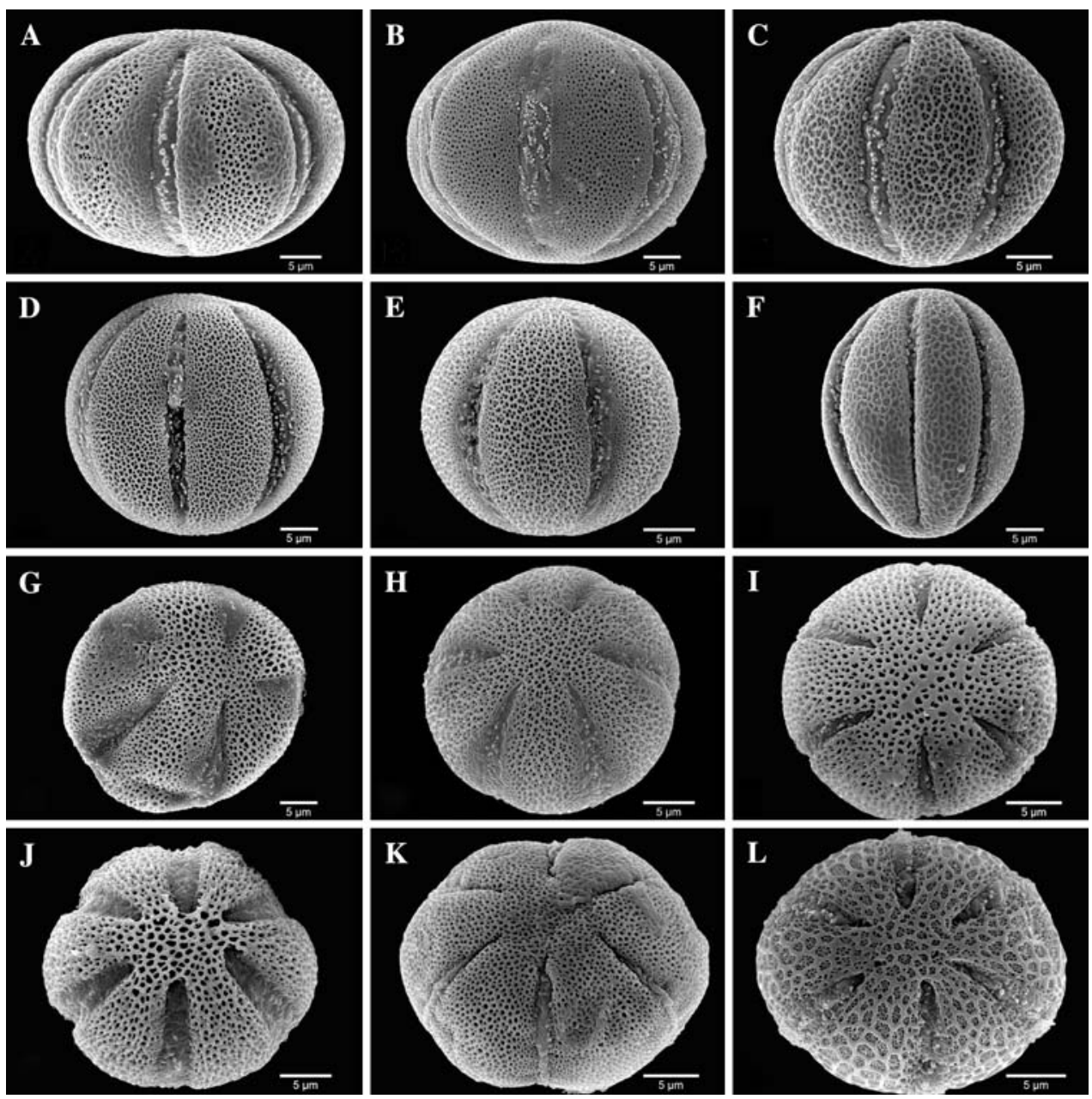

are regular and at the mesocolpia over ten secondary lumina per primary lumen were counted. The secondary lumen size and number decreases towards the poles and apertures. Observed in: Cleonia, Cyclotrichium, Hyssopus, Thymbra (Fig. 2c, d). Type I-3: The primary muri are irregular in pattern and sometimes discontinuous. Each primary lumen contains more than 20 rounded secondary lumina. Observed in: Heterolamium, Prunella (Fig. 2e).

\section{Type II: microreticulate}

Two subtypes are recognized based on the possible presence of tectal connections in the lumina. Type II-1: Microreticulate without secondary tectal connections. Observed in: Blephilia, Bystropogon, Cunila, Hedeoma, Hesperozygis, Hoehnea, Micromeria, Minthostachys, Monarda punctata, Neoplingia, Poliomintha, Pycnanthemum, Saccocalyx, Satureja, Zataria (Fig. 2f-h). Type II-2: The basic exine ornamentation is microreticulate, but secondary tectal connections are present in this subtype. Some perforations are elongated and subdivided into two or three smaller units by muri at a slightly lower plane. Observed in: Acanthomintha, Clinopodium, Conradina, Dicerandra, Glechon, Mentha, Origanum, Pentapleura, Piloblephis, Pogogyne, Rhabdocaulon, Stachydeoma (Fig. 2i, j).

\section{Type III: perforate}

The exine ornamentation is perforate. The distance between the edges of adjacent perforations is greater than the diameter of perforations. Observed in: Cuminia, Rhododon, Monarda fistulosa and Obtegomeria (Fig. 2k).

\section{Pollen wall stratification and ultrastructure}

All taxa studied show the same exine stratification (Fig. 3). The tectum is thicker than the foot layer. Columellae are simple, unbranched and densely spaced. The foot layer is continuous or distinctly discontinuous (Fig. 3c-e), relatively thin and supported by a very thin, often hardly discernible endexine (Fig. 3c-e). The intine is thicker below the colpi than at the mesocolpia (Fig. 3b, e). Pollenkitt is accumulated in the infratectum (Fig. 3e). 
Fig. 2 SEM micrographs of variation of exine ornamentation in Menthinae. Variations of bireticulate exine ornamentation; a Thymus serpyllum, b Melissa officinalis, c Hyssopus officinalis, d Cleonia lusitanica, e Heterolamium debile. Reticulate exine ornamentation; $\mathbf{f}$ Minthostachys mollis, $\mathbf{g}$ Poliomintha longiflora, $\mathbf{h}$ Hesperozygis nitida. Reticulate exine ornamentation with possible secondary tectal connections visible; i

Stachydeoma graveolens, $\mathbf{j}$ Piloblephis rigida. Variation of exine ornamentation in the genus Monarda; k perforateMonarda fistulosa, $\mathbf{I}$ reticulateMonarda punctata
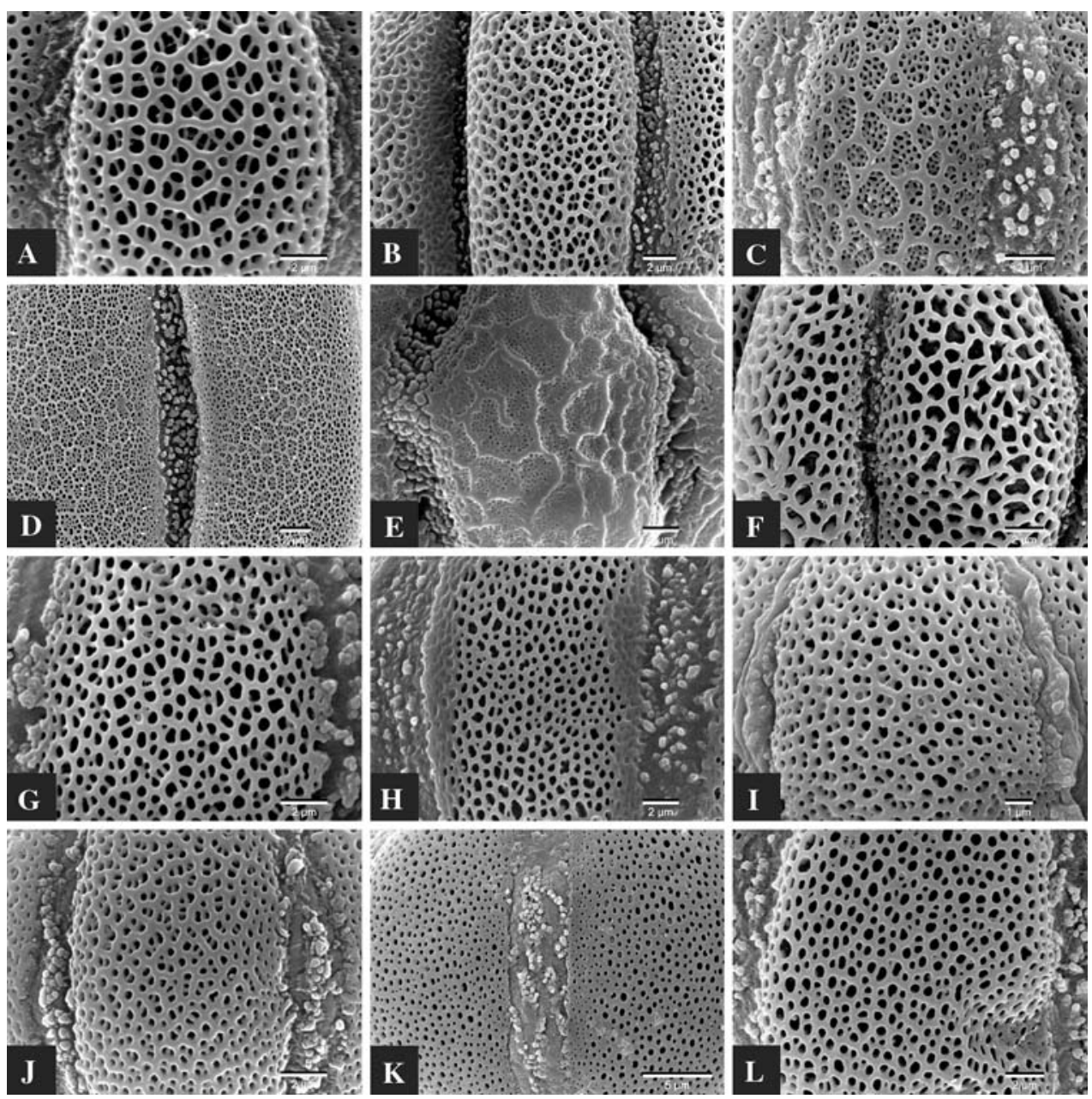

Orbicules

Orbicules were absent in all species investigated (Fig. 4). The inner locule wall displays a characteristic annular or star shaped pattern because of the prominent underlying endothecium thickenings (Fig. 4d). The tapetal membrane is completely smooth without any sporopollenin deposition (Fig. 4d-f).

\section{Discussion}

Menthinae are a stenopalynous group. Their pollen is small to medium size $(P=13.0-43.3 \mu \mathrm{m})$, hexacolpate (mixed with few pentacolpate pollen grains in Prunella vulgaris and Pycnanthemum incanum) with an oblate to prolate shape, and a perforate, microreticulate or bireticulate exine ornamentation. The colpus membranes are beset with granules and the exine stratification typically shows simple columellae. Orbicules are consistently absent.
Pollen features of Menthinae compared to other members of tribe Mentheae

There is ample evidence in the literature that the size of pollen grains is greatly affected by different preparation treatments and generally critical point-dried pollen is smaller than acetolysed pollen grains in SEM (Harley 1992; Lens et al. 2005; Moon et al. 2008a, b; Reitsma 1969; Schols et al. 2004). The present results are based on critical point dried anthers in order to conserve optimally the natural size and shape. Although the size varies between taxa of Menthinae, it is notable that the range of size variation is more or less constant within the same genus (Table 2).

In Menthinae, we found some pentacolpate pollen grains in Prunella vulgaris and Pycnanthemum incanum. This aperture heteromorphism was known in 17 species belonging to eight genera in tribe Mentheae (hexacolpate is always dominant but mixed together with tetra-, penta- or octocolpate pollen; Moon et al. 2008a, b; Trudel and Morton 1992). Even if aperture heteromorphism might offer an evolutionary advantage due to an increased 


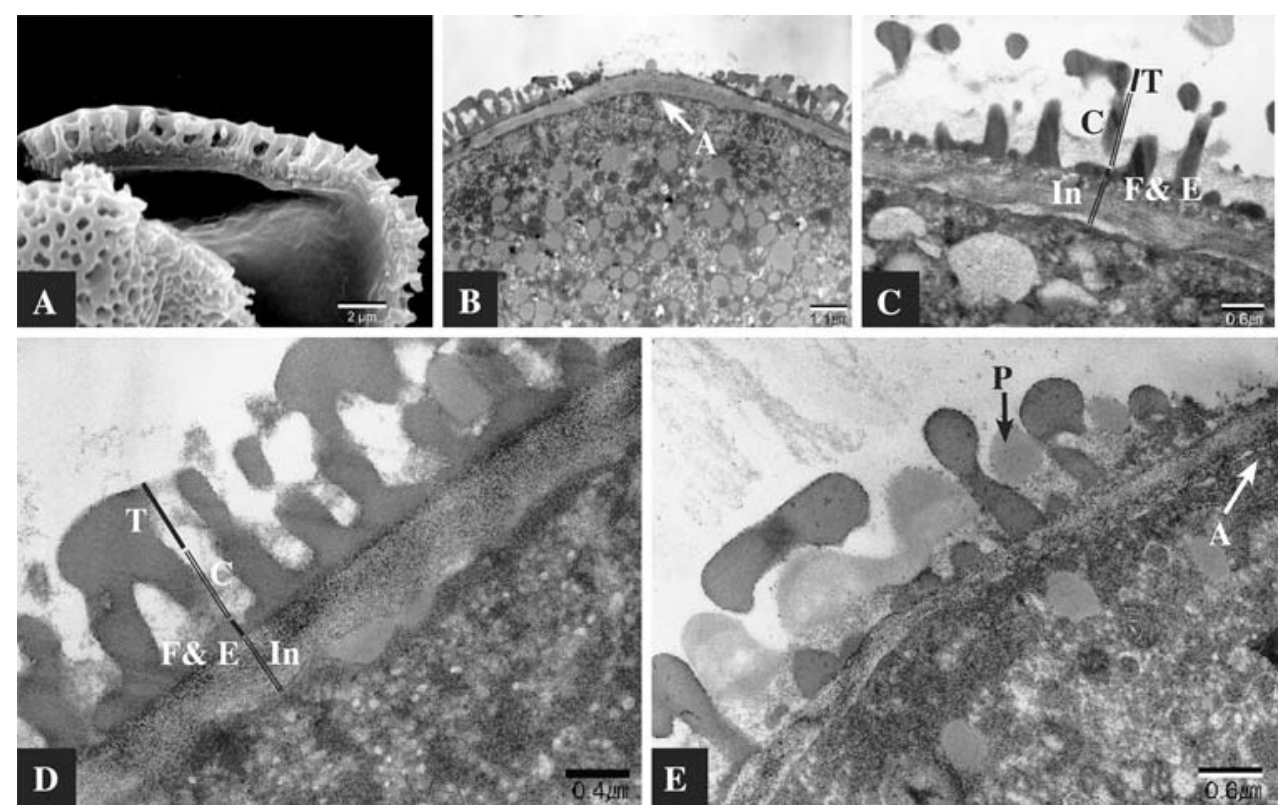

Fig. 3 SEM and TEM micrographs of pollen wall of Menthinae. a Cross section through exine of Zataria multiflora. b-h TEM observations of the ultrastruture of the pollen wall. b Exine thickness decreases towards the apertures $(A)$ while the intine is thicker below the colpi than at the mesocolpia; Hyssopus officinalis. c-e Magnified part of the pollen wall showing tectum $(T)$, columellae $(C)$, foot layer
$(F)$, endexine $(E)$ and intine $(I n)$. c Foot layer is discontinuous and endexine is hardly divided with foot layer; Satureja spinosa. d Foot layer is continuous; Hyssopus officinalis. e Exine is thicker below the mesocolpia than at the apertures $(A)$ and deposition of pollenkitt (black arrows) in the infratectum; Thymus serpyllum
Fig. 4 SEM micrographs of Menthinae. a Anther with two thecae of Hoehnea minima. b The completely dehisced stamen showing the inner locule wall without orbicules;

Ziziphora capitata. c Structure of the endothecium thickenings in cross section of Stachydeoma graveolens. d Inner locule wall with no traces of orbicules of Monardella macrantha, left; inner locule wall, right; detail of star-shaped endothecium cells. Detail of annular shaped endothecium cells without orbicules; e Piloblephis rigida, f Ziziphora clinopodioides
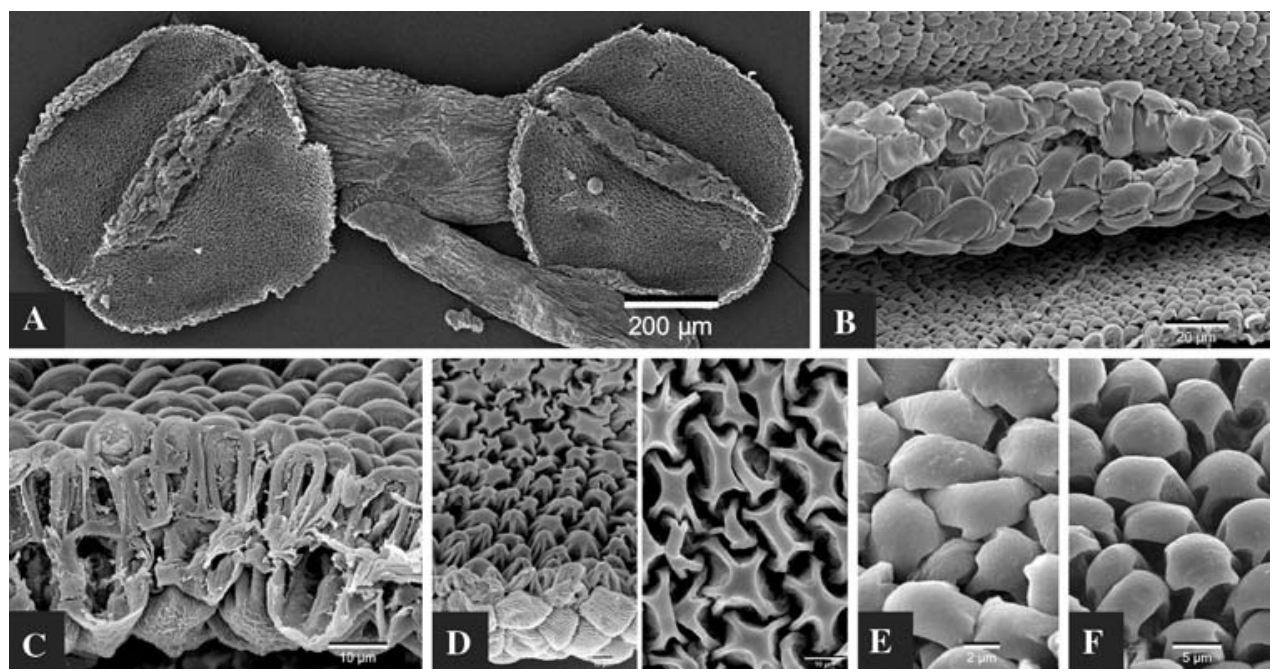

germination success (Dajoz et al. 1995; Furness and Rudall 2004; Mignot et al. 1994), it occurs rarely and only a very limited number of pollen grains are affected (less than 5\%). In addition, aperture heteromorphism occurs often in cultivated individuals (A.J. Paton, personal communication), and it could therefore be induced by atypical ecological circumstances. Our results show that all taxa studied in Menthinae have predominantly hexacolpate pollen, which supports hexacolpate pollen as a synapomorphy for
Nepetoideae. Simple columellae are plesiomorphic and found in most gynobasic-styled Labiatae (Abu-Asab and Cantino 1992). All taxa studied in Menthinae have simple columellae and a continuous or discontinuous foot layer with hardly observable endexine (Fig. 3c-e). Such an exine stratification also occurs in subtribes Salviinae and Nepetinae, and is common in subfamily Nepetoideae (Harley 1992; Harley et al. 1992; Moon and Hong 2003; Moon et al. 2008a, b; Nabli 1976). 
Exine ornamentation variation in Menthinae

The observed variation in exine ornamentation could be defined as bireticulate, microreticulate and perforate. Microreticulate exines are most common in Menthinae while a bireticulum is common in Salviinae and Nepetinae and in other Lamiaceae as well (Abu-Asab and Cantino 1992, 1994; Jamzad et al. 2000; Moon et al. 2008a, b; Trudel and Morton 1992; Wagstaff 1992). The shared subtype of bireticulate exine suggests a close relationship between Cleonia and Cyclotrichium, Hyssopus and Thymbra, while Gontscharovia has a similar exine pattern as Horminum, Monardella, Thymus and Ziziphora. Historically, Cleonia was considered related with Prunella (Table 1; Briquet 1897; Wunderlich 1967). In addition the molecular phylogeny suggested Horminum as a sister genus of Cleonia and Prunella (Walker and Sytsma 2007). The exine type corroborates this assumption, since all three genera possess bireticulate pollen even though we can find slight intergeneric differences in ornamentation (type I; Fig. 2d, e). Minthostachys has once been included in Bystropogon (Table 1; Bentham 1876; Briquet 1897); their similar exine ornamentation indeed confirms a close relationship between these genera. A similar example could be found in the genera Poliomintha, Rhabdocaulon and Stachydeoma, which possess a similar exine as Hedeoma (Table 1). Perforate exine ornamentations were found in Cuminia, Obtegomeria, Rhododon and Monarda fistulosa. It should be noted that bireticulate pollen with 10-20 secondary lumina is restricted to Old World taxa (Cleonia, Cyclotrichium, Hyssopus, Thymbra) while perforate pollen was found only in New World taxa (Cuminia, Monarda fistulosa, Obtegomeria, Rhododon; Table 2). In fact, bireticulate pollen occurs generally in Old World taxa except for the New World genus Monardella (Table 2).

At generic level, exine sculpturing appears as a stable character, except for Monarda (Table 2; Fig. 2k, 1). The variation in exine patterns found in Monarda seems to correlate with its subgeneric classification. Monarda fistulosa (subgenus Monarda) for instance possesses perforate grains and Monarda punctata (subgenus Cheilyctis) reticulate grains (Fig. 2k, 1; Prather et al. 2002). However, our sampling for the genus Monarda is insufficient $(2 / 20$ species) to address the infrageneric relationships based on pollen data alone.

Systematic implications of exine ornamentation at tribal level

The most recent accepted classification of tribe Mentheae (Harley et al. 2004) included many genera from different, previously recognized tribes (Table 1). Although tribe Mentheae is a well-supported monophyletic group, the subtribal delimitation and the relationships between genera are still poorly resolved (Cantino 1992; Harley et al. 2004; Trusty et al. 2004; Wagstaff et al. 1995; Walker and Sytsma 2007). In the most recent phylogenetic hypothesis produced by Walker and Sytsma (2007), subtribe Salviinae appears as a monophyletic group. However, subtribe Menthinae splits into two major lineages and genus Lycopus of the Menthinae is sister to subtribe Nepetinae. It should be mentioned that this molecular study was focused on genus Salvia with related genera and includes only 35 out of 65 Mentheae genera (Walker and Sytsma 2007). Nevertheless, to date this phylogeny is the most comprehensive one of the Mentheae (Walker and Sytsma 2007; Fig. 5).

The different exine patterns recognized evolved independently several times throughout the Mentheae (Fig. 5). Subtribe Salviinae possesses mainly bireticulate pollen except for Lepechinia and Chaunostoma, which have perforate pollen. The perforate exines of Lepechinia and Chaunostoma of Salviinae support that these genera are sister to all other genera within Salviinae (Epling 1948; Moon et al. 2008a). According to molecular topologies, Salvia is not a monophyletic group (Walker et al. 2004; Walker and Sytsma 2007) and pollen characters provide further evidence for this finding (Moon et al. 2008a). Interestingly bireticulate exines with thin primary muri or with a secondary reticulum with large lumina are restricted to Salvia clade I (Moon et al. 2008a). In addition, these features could be interpreted as more derived based on a reduced tectal surface (Walker and Doyle 1975). Reticulate exine patterns occur mainly in Menthinae clade I. The sister group of Menthinae clade I consists of subtribe $\mathrm{Ne}$ petinae and Menthinae clade II (Lycopus, Cleonia, Prunella and Horminum). Menthinae clade II has problematic subtribal delimitations. Trusty et al. (2004) demonstrated conflicting results with traditional taxonomy showing that Hyssopus (Menthinae) is closely related with Lallemantia (Nepetinae), while Horminum (Menthinae), Nepeta (Nepetinae) and Prunella (Menthinae) grouped together based on macromolecular data. The shared bireticulate exine ornamentation supports that Menthinae clade II and Nepetinae clade are closely related (Fig. 5). The taxonomic position of Lycopus has been problematic because of contradictory placements in different molecular phylogenies (Bräuchler et al. 2005; Trusty et al. 2004; Wagstaff et al. 1995; Walker and Sytsma 2007). For instance, the results of cpDNA restriction site analyses by Wagstaff et al. (1995) showed that Lycopus is sister to the major Menthinae clade, while combined analysis of the chloroplast regions $\operatorname{trn} \mathrm{L}-\mathrm{F}, p s b \mathrm{~A}-t r n \mathrm{H}$ and the nuclear rDNA ITS suggested Lycopus as a sister of the Nepetinae clade (Walker and Sytsma 2007). However, the palynological data of Lycopus provide evidence for a relationship 


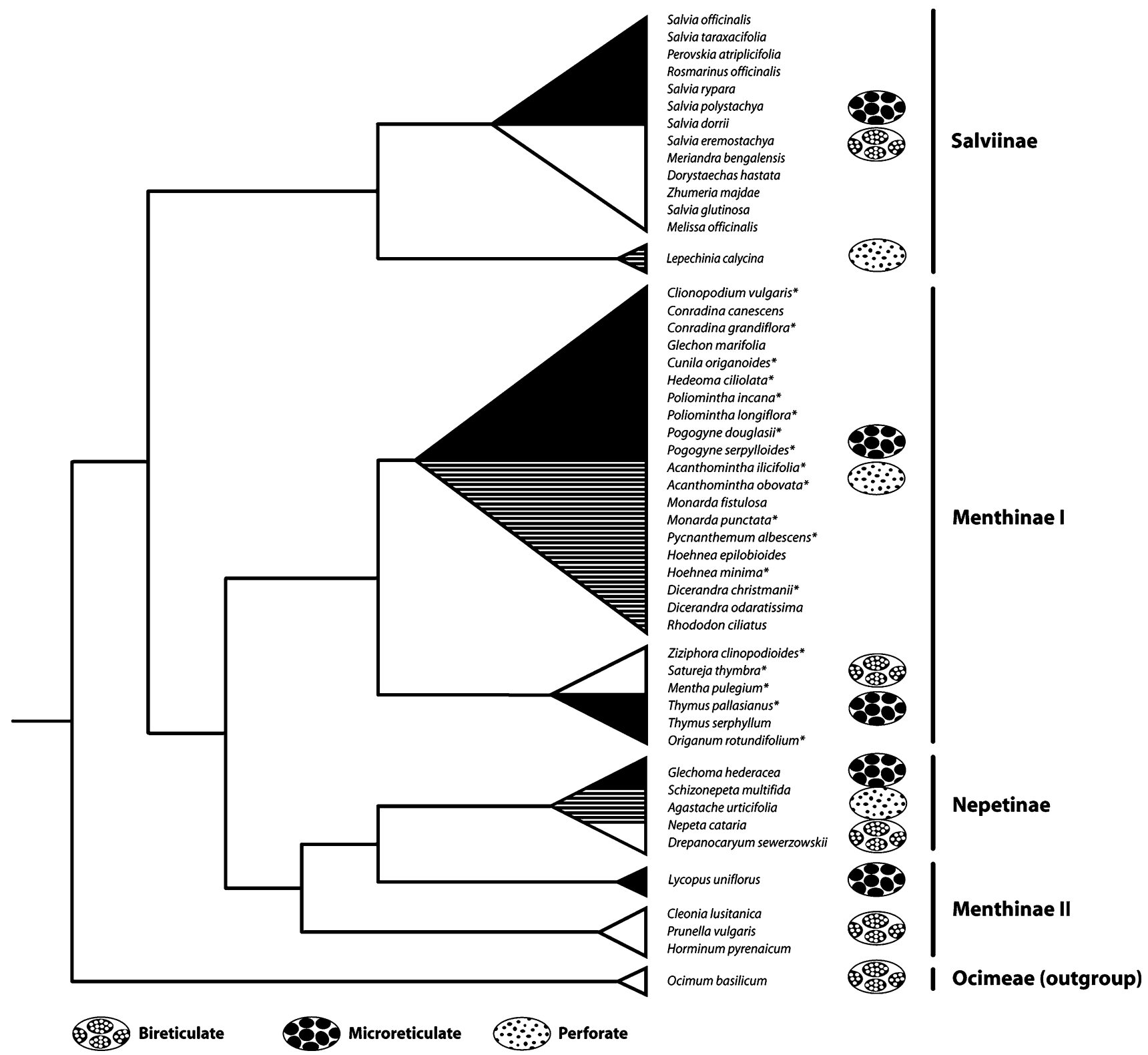

Fig. 5 Diagrams of different exine patterns in Mentheae and their distribution on the most recent molecular phylogenetic tree (simplified tree based on Walker and Sytsma 2007; their Figs. 3, 4). The three major types of exine ornamentation recognized were plotted on the topology; their occurrence in each clade is indicated as follows without reference to individual species (white bireticulate, black reticulate, stripe perforate). The taxa indicated by an asterisk were included in the present study but lacking in Walker and Sytsma (2007) - their phylogenetic position is estimated by assuming that genera are monophyletic

Salviinae show a clear distinction between primary and secondary reticula, while bireticulate pollen of Nepetinae has a rather vague distinction between the two incongruent reticula (Moon et al. 2008a, b).

\section{Genera of uncertain affinity}

The present study included two genera of uncertain subtribal affinity, Heterolamium and Melissa. Heterolamium is 
endemic to China and historically this genus belonged to Orthosiphon. However, Orthosiphon debile Hemsl. has been accepted as an independent genus Heterolamium based on its distinct anther and corolla characters ( $\mathrm{Li}$ and Hedge 1994). According to the most recent classification of Lamiaceae (Harley et al. 2004) Heterolamium belongs to tribe Mentheae without any indication of its subtribal position. Heterolamium has bireticulate pollen with discontinuous primary lumina consisting of over 20 secondary lumina (type I3, Fig. 2e). Although Prunella possesses the same exine type as Heterolamium, Prunella belongs to the problematic Menthinae clade within subtribe Nepetinae. Furthermore, its exine ornamentation resembles species of Drepanocaryum, Lophanthus and Nepeta, which are all members of Nepetinae (Moon et al. 2008b). In addition, Heterolamium is characterized by 15 calyx nerves and four stamens with the posterior pair longer than the anterior, both features being synapomorphies of Nepetinae (Harley et al. 2004). In conclusion, our results strongly support a position for Heterolamium in subtribe Nepetinae.

The genus Melissa consists of four species, distributed through Europe, North Africa, Macaronesia and Asia. Melissa was previously placed in subtribe Melissinae of tribe Satureieae together with several other genera, which currently belong to subtribe Menthinae (Table 1; Bentham 1876; Briquet 1897; Wunderlich 1967). Recent molecular phylogenies suggest Melissa as a member of subtribe Salviinae in Mentheae (Trusty et al. 2004; Walker and Sytsma 2007). Melissa has bireticulate pollen grains. The primary muri are thick with rounded primary lumina and the number of secondary lumina is $5-10$ per primary lumen (Fig. 2b). This kind of exine ornamentation is very similar to the ornamentation pattern in the genera Dorystaechas, Meriandra, Perovskia and Rosmarinus of the subtribe Salviinae (Moon et al. 2008a), supporting the hypothesized relationship between these genera (Walker et al. 2004; Walker and Sytsma 2007). Thus, palynological data support the inclusion of Melissa into the Salviinae. However, within subtribe Menthinae, a similar exine ornamentation was found in taxa from genera Gontscharovia, Horminum, Monardella, Thymus and Ziziphora (Table 2).

\section{Lack of orbicules}

In general, the presence of orbicules is considered as a plesiomorphic trait. Indeed, in angiosperms orbicules are mainly restricted to species possessing a secretory tapetum, which is predominantly present in the early diversified lineages of flowering plants (i.e., Furness and Rudall 1998; Huysmans et al. 1998). In Chloanthaceae (currently tribe Chloantheae of Lamiaceae sensu Harley et al. 2004), variation in shape and surface patterns of orbicules was found to be taxonomically useful (Raj and El-Ghazaly 1987). All genera investigated of Mentheae are lacking orbicules (Moon et al. 2008a, b). The locule wall is smooth, with no traces whatsoever of orbiculelike sporopollenin deposition. The absence of orbicules in Mentheae and their presence in tribe Chloantheae actually confirms the plesiomorphic nature since tribe Chloantheae belongs to the basal Lamiaceae subfamily Prostantheroideae (Harley et al. 2004; Raj and El-Ghazaly 1987). However, a study on Lavandula dentata (tribe Ocimeae of subfamily Nepetoideae sensu Harley et al. 2004; Suarez-Cervera and Seoane-Camba 1986) showed that this species has a secretory tapetum without orbicule formation. The tapetum type of Mentheae is unknown and therefore further ontogenetical studies of both pollen and tapetal cells will be necessary to provide insight in the relationship between tapetum type and orbicule occurrence.

\section{Conclusion}

Mentheae is a stenopalynous group with hexacolpate pollen, perforate/microreticulate/bireticulate exine ornamentation and a pollen wall stratification with simple unbranched columellae. Variation in exine ornamentation may have systematic importance particularly at generic level. Our results suggest Heterolamium to be a member of subtribe Nepetinae and Melissa to belong to subtribe Salviinae. The exine variation observed in Monarda might have potential taxonomic value at subgeneric level. However, we found variability in some pollen characters between closely related species and a remarkable association between specific exine ornamentation types and the major geographic areas. A phylogenetic study of Mentheae (combining morphology and macromolecules) based on a relevant sampling will be necessary to illuminate the enigmatic intergeneric relationships. The present study provides pollen morphological characters that hopefully will be added in future phylogenetic analyses.

Acknowledgments We thank the directors of the herbaria of BR, G, $\mathrm{GH}, \mathrm{K}, \mathrm{LV}, \mathrm{MO}$ and $\mathrm{S}$ for permitting the examination of specimens, either through loans or during visits. Sincere thanks also to two anonymous reviewers for their critical reading of manuscript and helpful suggestions. We are also grateful to Anja Vandeperre (K.U.Leuven) and An Vandoren (TEM, K.U.Leuven) for technical assistance. H.K. Moon thanks Dr. Alan Paton (Royal Botanic Gardens, Kew) for valuable discussions and Dr. Frederic Lens (K.U.Leuven) for helpful comments that improved this manuscript. A personal research grant of the K.U.Leuven (DB/06/054) was awarded to H.K. Moon. The Fund for Scientific Research-Flanders (FWO, G.0268.04 and G.0250.05) and the K.U.Leuven (OT/05/35) financially supported this research. S. Vinckier was a postdoctoral fellow of the Fund for Scientific Research-Flanders (FWO) during the course of this study. 


\section{Appendix}

Table 3

Table 3 Voucher specimens of subtribe Menthinae that are examined in the present study

\begin{tabular}{|c|c|}
\hline Species & Voucher specimens \\
\hline Acanthomintha ilicifolia A.Gray & USA, 26-29.05.1915. Dutton \& Walker 3819 BR \\
\hline Acanthomintha obovata Jeps. & USA, 18.05.1919. Walker 5094 BR \\
\hline Blephilia ciliata (L.) Benth. & USA, 13.06.1966. Radford 44758 BR \\
\hline Blephilia hirsuta (Pursh) Benth. & USA, 12.07.1966. Radford 44922 BR \\
\hline Bystropogon canariensis (L.) L'Hér & Canary Is., without date, Bullemont 1855 BR \\
\hline Bystropogon canarensis var. smithianus H.Christ & Canary Is., 15.05.1901. Bornmüller 2765 BR \\
\hline Cleonia lusitanica (L.) L. & Morocco, 13.05.1934. Wall $45 \mathrm{~S}$ \\
\hline Clinopodium vulgare L. & Cultivated in KEW accession no.: 1994-2824 \\
\hline Conradina canescens A. Gray & USA, 30.11.1969. Godfrey 69283 BR \\
\hline Conradina grandiflora Small & USA, 24.10.1956. Ahles \& Bell 21395 BR \\
\hline Cuminia eriantha var. fernandezia (Colla) Harley & Chile, 23.11.1991. Billiet \& Jadin 5631 BR \\
\hline Cunila origanoides (L.) Britton & USA, 07.09.1897. Anonymous 323b BR \\
\hline Cyclotrichium origanifolium (Labill.) Manden. & Lebanon, 06.07.1897. Bornmüller 1260, BR \\
\hline Dicerandra christmanii Huck \& Judd & USA, 11.09.1987. Skean, Jr. 2130 MO \\
\hline Dicerandra odoratissima R.M.Harper & USA, 17.09.1967. Radford \& Leonard 11479 BR \\
\hline Glechon marifolia Benth. & Uruguay, 12.02.1955. Pedersen 3627 BR \\
\hline Gontscharovia popovii (B. Fedtsch. \& Gontsch.) Boriss. & URSS, 31.08.1931. Anonymous $206 \mathrm{~K}$ \\
\hline Hedeoma ciliolata (Epling \& W.S.Stewart) R.S.Irving & Mexico, 01.10.1954. Rzedowski 5003 GH \\
\hline Hesperozygis nitida (Benth.) Epling. & Brazil, 22.09.1976. Dombroswski 6442 K \\
\hline \multirow[t]{2}{*}{ Heterolamium debile (Hemsl.) C. Y. Wu } & China, 03.1889. Henry s.n. K \\
\hline & China, 1885-1888. Henry 5770 GH \\
\hline Hoehnea epilobioides (Epling) Epling & Brazil, 23.10.1974. Kummrow $688 \mathrm{~K}$ \\
\hline Hoehnea minima (Schmidt) Epl. & Brazil, 26.01.1916. Dusén 17542 GH \\
\hline Horminum pyrenaicum $\mathrm{L}$. & Italy, 26.06.1969. Cnops 21169 BR \\
\hline \multirow[t]{2}{*}{ Hyssopus officinalis $\mathrm{L}$. } & Spain, 22.09.1974. Bondía et al., 1242 GF BR \\
\hline & Cultivated in KEW accession no.: $1975-1170 \mathrm{~K}^{\mathrm{a}}$ \\
\hline Melissa flava Benth. & India, without date, Strachey and Winterbottom 1 BR \\
\hline \multirow[t]{3}{*}{ Melissa officinalis $\mathrm{L}$. } & France, 1986. Sotiaux s.n. BR \\
\hline & Spain, 1869. Bourgeau s.n. BR ${ }^{\mathrm{a}}$ \\
\hline & Cultivated in KEW accession no.: $1994-2690 \mathrm{~K}^{\mathrm{a}}$ \\
\hline Mentha pulegium $\mathrm{L}$. & Cultivated in KEW accession no.: $1994-1897 \mathrm{~K}^{\mathrm{a}}$ \\
\hline Micromeria marginata $(\mathrm{Sm}$.) Chater & Cultivated in KEW accession no.: $1995-1960 \mathrm{~K}^{\mathrm{a}}$ \\
\hline Minthostachys mollis Griseb & Ecuador, 10.08.1939. Asplund s.n. BR \\
\hline Monarda fistulosa $\mathrm{L}$. & USA, 06.08.1973. Bouharmont 8498. BR \\
\hline Monarda punctata $\mathrm{L}$. & USA, 26.10.1957. Ahles \& Haesloop 38096 BR \\
\hline Monardella macrantha A.Gray & Cultivated in KEW accession no.: $1980-998 \mathrm{~K}^{\mathrm{a}}$ \\
\hline Monardella nana A. Gray & Cultivated in KEW accession no.: $1999-270 \mathrm{~K}^{\mathrm{a}}$ \\
\hline Monardella odoratissima Benth. & USA, 29.08.1969. Howell 46064 BR \\
\hline Neoplingia leucophylloides Ramamoorthy & Mexico, 05.08.1982. Hiriart \& Medrano 12792 K \\
\hline Obtegomeria caerulescens (Benth.) Doroszenko & USA, 16.08.1986. Hermes, Cuadrov \& Gentry 2706 MO \\
\hline Origanum rotundifolium Boiss. & Cultivated in KEW accession no.: $1968-19106 \mathrm{~K}^{\mathrm{a}}$ \\
\hline Pentapleura subulifera Hand.-Mazz. & Iraq, 4-9. 07. 1957. Rechinger $12085 \mathrm{~K}$ \\
\hline Piloblephis rigida (Bartram ex Benth.) Raf. & USA, 13.02.1995. Holst et al. $4543 \mathrm{MO}$ \\
\hline Pogogyne douglasii Benth. & USA, California, 31.05.1892. Bioletti s.n. BR \\
\hline
\end{tabular}


Table 3 continued

\begin{tabular}{|c|c|}
\hline Species & Voucher specimens \\
\hline Pogogyne serpylloides (Torr.) Gray & USA, California, 28.04.1964. Rose 64044 BR \\
\hline Poliomintha incana (Torr.) A.Gray & USA, 18.06.1985. Whiting 756/731 GH \\
\hline Poliomintha longiflora A.Gray & Mexico, 11.09.1955. Rzedwskiz 6583 GH \\
\hline \multirow[t]{3}{*}{ Prunella vulgaris $\mathrm{L}$. } & UK, 03.07.1886. Bailey 1132 LV $^{\mathrm{a}}$ \\
\hline & Belgium, 17.06.2005. Moon LV \\
\hline & Cultivated in KEW accession no.: $1994-2824 \mathrm{~K}^{\mathrm{a}}$ \\
\hline Pycnanthemum albescens Torr. \& A.Gray. & USA, 27.08.1982. Kessler et al. 2648 BR \\
\hline Pycnanthemum incanum (L.) Michx. & USA, 10.09.1966. Bradley et al. 3491 BR \\
\hline Rhabdocaulon coccineum (Benth.) Epling & Brazil, 12.04.1977. Harley 20332 K \\
\hline Rhabdocaulon strictum (Benth.) Epl. & Argentina, 18.04.1979. Persen $12455 \mathrm{GH}$ \\
\hline Rhododon ciliatus (Benth.) Epl. & USA, 06.06.1969. Correll 37399 GH \\
\hline Saccocalyx satureioides Coss. \& Durand & Algeria, 26.05.1965. Faurel et al. 5650 BR \\
\hline Satureja thymbra L. & Cultivated in KEW accession no.: 2001-823 $\mathrm{K}^{\mathrm{a}}$ \\
\hline Satureja spinosa $\mathrm{L}$. & Cultivated in KEW accession no.: 1989-3009 $\mathrm{K}^{\mathrm{a}}$ \\
\hline \multirow[t]{2}{*}{ Stachydeoma graveolens (Chapm. ex A. Gray) Small } & USA, 18.08.1962. Godfrey 62494 BR \\
\hline & USA, 18.08.1962. Godfrey 62494 BR \\
\hline \multirow[t]{2}{*}{ Thymbra spicata $\mathrm{L}$. } & Italy, 18.06.1883. Ascherson 470 BR \\
\hline & Cultivated in KEW accession no.: $2001-825 \mathrm{~K}^{\mathrm{a}}$ \\
\hline Thymus pallasianus & Cultivated in KEW accession no.: 2001-4194 $\mathrm{K}^{\mathrm{a}}$ \\
\hline Thymus serpyllum & Cultivated in KEW accession no.: 1973-21043 K \\
\hline Zataria multiflora Boiss. & Iran, 16.05.1892. Bornmüller $4274 \mathrm{GH}$ \\
\hline Ziziphora clinopodioides Lam. & Turkey, 01.09.1993. Vašák s.n. BR \\
\hline
\end{tabular}

All taxa were investigated by scanning electron microscopy

a The selected taxa also observed by transmission electron microscopy

\section{References}

Abu-Asab MS, Cantino PD (1992) Pollen morphology in subfamily Lamioideae (Labiatae) and its phylogenetic implications. In: Harley RM, Reynolds T (eds) Advances in Labiatae science. Royal Botanic Gardens, Kew, pp 97-112

Abu-Asab MS, Cantino PD (1993) Systematic implications of pollen morphology in Caryopteris (Labiatae). Syst Bot 18:502-515

Abu-Asab MS, Cantino PD (1994) Systematic implications of pollen morphology in subfamilies Lamioideae and Pogostemonoideae (Labiatae). Ann Missouri Bot Gard 81:653-686

Afzal-Rafii Z (1983) Les pollens du genre Salvia et leur évolution. Pollen \& Spores 25:351-366

Bentham G (1876) Labiatae. In: Bentham G, Hooker JD (eds) Genera plantarum, vol 2. Reeve and Co, London, pp 1160-1196

Bräuchler C, Meimber H, Abele T, Heubl G (2005) Polyphyly of the genus Micromeria (Lamiaceae)—evidence from cpDNA sequence data. Taxon 54:639-650

Briquet J (1897) Labiatae. In: Engler A, Prantl K (eds) Die naturlichen Pflanzenfamilien nebst ihrer Gattungen und wichtigeren Arten, vol IV. Wilhelm Engelmann, Leipzig, pp 183-287

Cantino PD (1992) Evidence for a polyphyletic origin of the Labiatae. Ann Missouri Bot Gard 79:361-379

Cantino PD, Harley RM, Wagstaff SJ (1992) Genera of Labiatae: status and classification. In: Harley RM, Reynolds T (eds) Advances in Labiatae science. Royal Botanic Gardens, Kew, pp 511-522

Dajoz I, Mignot A, Hoss C, Till-Bottraud I (1995) Pollen aperture heteromorphism is not due to unreduced gametophytes. Amer J Bot 82:104-111
Demissew S, Harley MM (1992) Trichome, seed surface and pollen charaters in Stachys (Labiatae) in Tropical Africa. In: Harley RM, Reynolds $\mathrm{T}$ (eds) Advances in Labiatae science. Royal Botanic Gardens, Kew, pp 149-166

Epling C (1948) A synopsis of the tribe Lepechinieae (Labiatae). Brittonia 6:352-364

Erdtman G (1945) Pollen morphology and plant taxonomy. IV. Labiatae, Verbenaceae and Avicenniaceae. Svensk Bot Tidskr 39:279-285

Erdtman G (1960) The acetolysis method. A revised description. Svensk Bot Tidskr 54:561-564

Furness CA, Rudall PJ (1998) The tapetum and systematics in monocotyledons. Bot Rev 64:201-239

Furness CA, Rudall PJ (2004) Pollen aperture evolution-a crucial factor for eudicot success? Trends Pl Sci 9:154-158

Harley MM (1992) The potential value of pollen morphology as an additional taxonomic character in subtribe Ociminae (Ocimeae: Nepetoidaea: Labiatae). In: Harley RM, Reynolds T (eds) Advances in Labiatae science. Royal Botanic Gardens, Kew, pp $125-138$

Harley MM, Paton A, Harley RM, Cade PG (1992) Pollen morphological studies in tribe Ocimeae (Nepetoidaea: Labiatae): I. Ocimum L. Grana 31:161-176

Harley RM, Atkins S, Budantsev AL, Cantino PD, Conn BJ, Grayer R, Harley MM, De Kok R, Krestovskaja T, Morales R, Paton AJ, Ryding O, Upson T (2004) Labiatae. In: Kadereit JW (ed) The families and genera of vascular plants VII. Flowering plants-dicotyledons: Lamiales (except Acanthaceae including Avicenniaceae). Springer, Berlin, pp 167-275 
Henderson DM, Prentice H, Hedge IC (1968) Pollen morphology of Salvia and some related genera. Grana Palynol 8:70-85

Holmgren PK, Holmgren NH, Barnett LC (1990) Index herbariorum, part 1. The herbaria of the world, vol 120, 8th edn. Regnum Veg. New York Botanical Garden, Bronx, pp 1-693

Huysmans S, El-Ghazaly G, Smets E (1998) Orbicules in angiosperms: morphology, function, distribution, and relation with tapetum types. Bot Rev 64:240-272

Huysmans S, El-Ghazaly G, Smets E (2000) Orbicules: still a well hidden secret of the anther. In: Nordenstam B, El-Ghazaly G, Kassas M (eds) Plant systematics for the 21 st century. WennerGren International Series, vol 77. Portland Press, London, pp 201-212

Jamzad Z, Harley MM, Ingrouille M, Simmonds MSJ, Jalili A (2000) Pollen exine and nutlet surface morphology of the annual species of Nepeta L. (Lamiaceae) in Iran. In: Harley MM, Morton GM, Blackmore S (eds) Pollen and spores: morphology and biology. Royal Botanic Gardens, Kew, pp 385-397

Jamzad Z, Chase MW, Ingrouille M, Simmonds MSJ, Jalili A (2003) Phylogenetic relatioships in Nepeta L. (Lamiaceae) and related genera based on ITS sequence data. Taxon 52:21-32

Lens F, Dressler S, Vinckier S, Janssens S, Dessein S, Van Evelghem L, Smets E (2005) Palynological variation in Balsaminoid Ericales. I. Marcgraviaceae. Ann Bot 96:1047-1060

Li X, Hedge IC (1994) Heterolamium. In: Wu ZY, Raven PH (eds) Flora of China, vol 17. Science Press/Missouri Botanical Garden, Beijing/St Louis, pp 294-295

Mignot A, Hoss C, Dajoz I, Leuret C, Henry JP, Druillaux JM, Heberle-Bors E, Till-Bottraud I (1994) Pollen aperture polymorphism in the angiosperms; importance, possible causes and consequences. Acta Bot Gall 141:109-122

Moon HK, Hong SP (2003) Pollen morphology of the genus Lycopus (Lamiaceae). Ann Bot Fenn 40:191-198

Moon HK, Vinckier S, Walker JB, Smets E, Huysmans S (2008a) A search for phylogenetically informative pollen characters in the subtribe Salviinae (Mentheae: Lamiaceae). Int J Pl Sci 169:455471

Moon HK, Vinckier S, Smets E, Huysmans S (2008b) Comparative pollen morphology and ultrastructure of Mentheae subtribe Nepetinae (Lamiaceae). Rev Palaeobot Palynol 149:174-198. doi:10.1016/j.revpalbo.2007.12.001

Nabli MA (1976) Etude ultrastructurale comparee de l'exine chez quelques genres de Labiatae. In: Ferguson IK, Muller J (eds) The evolutionary significance of the exine. Academy Press, London, pp 499-525

Prather LA, Monfils AK, Posto AL, Williams RA (2002) Monophyly and phylogeny of Monarda (Lamiaceae): evidence from the internal transcribed spacer (ITS) regions of nuclear ribosomal DNA. Syst Bot 27:127-137

Punt W, Hoen PP, Blackmore S, Nilsson S, Le Thomas A (2007) Glossary of pollen and spore terminology. Rev Palaeobot Palynol 143:1-81
Raj B, El-Ghazaly G (1987) Morphology and taxonomic application of orbicules (Ubisch bodies) in Chloanthaceae. Pollen \& Spores 29:151-166

Reitsma T (1969) Size modifications of recent pollen under treatments. Rev Palaeobot Palynol 9:175-202

Rudall P (1980) Pollen morphology in the subtribe Hyptidinae (Labiatae). Kew Bull 35:453-458

Schols P, Dessein S, D'Hondt C, Huysmans S, Smets E (2002) Carnoy: a new digital measurement tool for palynology. Grana 41:124-126

Schols P, Es K, D'hondt C, Merchx V, Smets E, Huysmans S (2004) A new enzyme-based method for the treatment of fragile pollen grains collected from herbarium material. Taxon 53:777-782

Suarez-Cervera M, Seoane-Camba JA (1986) Ontogénèse des grains de pollen de Lavandula dentata L. et évolution des cellules tapétales. Pollen \& Spores 28:5-28

Trudel MC, Morton JK (1992) Pollen morphology and taxonomy in North American Labiatae. Canad J Bot 70:975-995

Trusty JL, Olmstead RG, Bogler DJ, Guerra AS, Francisco-Ortega J (2004) Using molecular data to test a biogeogrphic connection of the macaronesian genus Bystropogon (Lamiaceae) to the New World: a case of conflicting phylogenies. Syst Bot 29:702-715

Varghese TM, Verma DPS (1968) Pollen morphology of some Indian Labiatae. J Palynol 4:77-83

Vij SP, Kashyap SK (1975) Pollen grain studies in some Labiatae. J Palynol 11:29-42

Vinckier S, Smets E (2002) Morphology, ultrastructure and typology of orbicules in Loganiaceae s.l. and related genera, in relation to systematics. Rev Palaeobot Palynol 119:161-189

Wagstaff SJ (1992) A phylogenetic interpretation of pollen morphology in tribe Mentheae (Labiatae). In: Harley RM, Reynolds T (eds) Advances in Labiatae Science. Royal Botanic Gardens, Kew, pp 113-124

Wagstaff SJ, Olmstead RG, Cantino PD (1995) Parsimony analysis of cpDNA restriction site variation in subfamily Nepetoideae (Labiatae). Amer J Bot 82:886-892

Walker JW, Doyle JA (1975) The bases of angiosperm phylogeny: palynology. Ann Missouri Bot Gard 62:664-723

Walker JB, Sytsma KJ (2007) Staminal evolution in the genus Salvia (Lamiaceae): molecular phylogenetic evidence for multiple origins of the staminal lever. Ann Bot 100:375-391

Walker JB, Sytsma KJ, Treutlein J, Wink M (2004) Salvia (Lamiaceae) is not monophyletic: implications for the systematics, radiation, and ecological specializations of Salvia and tribe Mentheae. Amer J Bot 91:1115-1125

Waterman AH (1960) Pollen grain studies of the Labiatae in Michigan. Webbia 15:399-415

Wunderlich R (1967) Ein Vorschlag zu einer natürlichen Gliederung der Labiaten auf Grund der Pollenkörner, der Samenentwicklung und des reifen Samens. Oesterr Bot Z 114:383-483 